ISSN: 1576-0162

\title{
The Enlargement of the European Investment Plan AND THE EASTERN PARTNERSHIP
}

LA AMPLIACIÓN DEL PLAN EUROPEO DE INVERSIONES Y LA ASOCIACIÓN ORIENTAL

Cristina García Nicolás

Universidad de Castilla-La Mancha

cristina.garcia@uclm.es

Recibido: noviembre de 2018; aceptado: febrero de 2019

\section{ABSTRACT}

The success of the implementation of the European Investment Plan in 2015 has led not only to the extension of the European Investment Plan until 2020 and to the doubling of its financial capacity but also to the extension of its geographical framework. The new European External Investment Plan sets out some of the Juncker Plan's competitiveness objectives, linking them to the review of the European Neighbourhood Policy (2015). The objective of this work is to analyse the investment possibilities in the states of the socalled Eastern Partnership (Belarus, Ukraine, Moldova, Georgia, Armenia and Azerbaijan).

Keywords: investment; neighbourhood policy; competitiveness. 
RESUMEN

El éxito de la implantación del Plan Europeo de Inversiones en 2015 ha llevado a plantear no sólo su extensión hasta 2020 -y la duplicación de su capacidad financiera -, sino también la ampliaciōn de su marco geográfico. El nuevo Plan de Inversiones Exteriores recoge algunos de los objetivos de competitividad del Plan Juncker, vinculándolos a la revisiōn de la Política de Vecindad Europea (2015). El objetivo de este trabajo es analizar las posibilidades de inversión en los estados de la denominada Asociación Oriental (Bielorrusia, Ucrania, Moldavia, Georgia, Armenia y Azerbayān).

Palabras Clave: inversión; política de vecindad; competitividad.

Clasificación JEL: R58, H77. 


\section{INTRODUCTION}

The objective of this paper is to analyse the situation of those countries in which the new European External Investment Plan (EIP), presented by the European Commission in September 2016, will be applied. It is presented as 'an ambitious Plan, principally for Africa and the neighbouring countries of the EU'. Within this broad geographical area, we will focus on the Eastern dimension of the European Neighbourhood Policy (ENP), strongly promoted in 2009 by some of the new Member States with the creation of the Eastern Partnership: Belarus, Ukraine, Moldova, Georgia, Armenia, and Azerbaijan.

As was the case with the implementation of the European Investment Plan (the "Juncker Plan"), the External Investment Plan (EIP) lays out one of its motivations as reducing public and private investment in the neighbouring countries of the European Union. In the case of the members of the Eastern Partnership, it is not only a result of the economic crisis, but that, and in part linked to the crisis, the political situation should be taken into account, both internally and across the region as a whole, where the Russian Federation plays a fundamental political, economic and strategic role. All this immersed in a context of economic crisis, the intensification of migratory movements ${ }^{1}$ and the rise of terrorism, in which an economic investment policy could guarantee not only economic but also political, institutional, and social stability in the countries neighbouring the European Union.

And in the same way that the Juncker Plan relied on the economic, social, and territorial cohesion policies, the European Structural and Investment Funds (ESI Funds), as well as on the pre-existing investment programs offered by the European Investment Bank (EIB) and other various platforms, the EIP also has a framework of normative and financial support. In this case, the framework is defined by the European Neighbourhood Policy -reformed in 2015- and the Action Plans signed by each of the countries in the Eastern Partnership, the European Neighbourhood Instrument (ENI) together with the Investment Instrument of the Neighbourhood Policy (NIF), as well as some ElB programs, technical assistance (TAIEX), and support for the improvement of governance and management (SIGMA).

\footnotetext{
${ }^{1}$ On June 7, 2016, the Commission adopted a communication on establishing a new Partnership Framework with third countries under the European Agenda on Migration COM (2016) 385.
} 
One could also speak of an external dimension of the Europe 2020 Strategy, since the document refers to an expansion in creating opportunities for neighbouring countries. Opportunities that are closely linked to the competitiveness objective on which the Investment Plan for Europe is based. This competitiveness responds to a multifaceted concept in which aspects related to accessing basic services - healthcare and education - , institutional issues and indicators of democratic "health", as well as elements linked to innovation and the so-called "smart territories", are tied.

Finally, the global context in which we live requires us to consider the development of the European Union and its Member States within a framework of interrelation, not only of countries or territories, but also in terms of environmental considerations and human development. The European Union's Global Strategy highlights this interrelation with the 2030 Agenda, the United Nations Sustainable Development Goals and the Paris Agreement on Climate change (CP21). Obviously, these interrelations are transferred to the scope of the ENP and, in our case, of the Eastern Partnership.

Taking into account the elements outlined above, this work is organized as follows: the first section, following this introduction, will review the main features of the renewed European Investment Plan and its expansion outside European borders; the second section addresses the objectives of the European Neighbourhood Policy, which will be analysed from its initiation in 2003 and, above all, from the configuration of the Eastern Partnership, as well as the financing of its programs; and the third section focuses on the scenarios in which the European External Investment Plan is to be implemented, highlighting the challenges it faces as well as the possibilities that its application will offer. This study ends with a series of final reflections.

\section{The renewed Investment Plan for Europe}

The new European Strategic Investment Fund 2.0 has the mandate for its implementation included in the Bratislava Declaration of 16 September 2016, which combines the concerns already discussed in the introduction and encourages Member States to seek common solutions for the present and, above all, for the future ${ }^{2}$.

The success of the initial Investment Plan for Europe has led to considerations of a temporary and geographical expansion, as well as an increase in its intervention capacities and a reinforcement of additionality. Without losing sight of the competitiveness objectives, the emphasis will be on reinforced technical assistance and the elimination of obstacles for investments and the expansion of a single market.

2 See also: European Commission (2016): European Structural and Investment FUNDS and European Fund for Strategic Investments complementarities - Ensuring coordination, synergies and complementarity. 
To date, the expectations raised have been met, taking advantage of the experience of the Structural and Investment Funds, as well as the programs developed by the European Investment Bank (EIB) and numerous existing platforms (García Nicolás, 2016: 181-184). The new concept of "additionality" introduced in Article 5 of the EFSI Regulation, according to which investments will correct market failures or sub-optimal investment situations, has also been applied.

However, the independent evaluation carried out on the operation period of the EFSI and the Investment Platform presents some issues that the temporary and geographical extension would have to address and correct. The distribution of funds depends on demand, and the results show that 91 per cent of the EFSI has been allocated to the EU-15. Among the causes for this is a lower level of competitiveness in the countries in central-eastern Europe, that is, the EU-13 (EY, 2016: 2-6). Despite the fact that the biggest beneficiaries are SMEs - due to a combination of the EFSI and the ESI Funds, and with the investments of the EIB (COSME and InnoFin ${ }^{3}$ - , and the processes and resolutions are not as fast as expected, the consultation seems to support high effectiveness and efficiency in investment management. The second major group of investments are those related to infrastructure and innovation. It has also been determined that cross-border infrastructure projects (including related services) provide additionality, given their importance on the single market. In addition, in the future, the $\mathrm{EFSI}^{4}$ will focus even more on sustainable investments in all sectors to contribute to the achievement of the CP21 objectives and promote the transition to a circular economy, efficient in the use of resources and without carbon emissions.

The European External Investment Plan (EIP) will take advantage of the experience gained with the current investment programs at an EU level, as stated in Regulation 2015/1017, which gives the green light to the expansion of the European Investment Plan and its implementation outside the EU5 .

In light of the objectives of these investment programs, the EIP will rely on a new investment fund, the European Fund for Sustainable Development (EFSD), which combines its activities with a new guarantee to tackle and unblock

\footnotetext{
${ }^{3}$ COSME is a program aimed at the competitiveness of SMEs, with a budget of 2.3 billion euros for the period 2014-2020. InnovFin is a joint initiative of the EIB Group and the European Commission within the Horizon 2020 program.

${ }^{4}$ COM (2016) 597 final, 2016/0276 (COD). Proposal for a Regulation of the European Parliament and of the Council amending Regulations (EU) No 1316/2013 and (EU) 2015/1017 with regard to the extension of the duration of the European Fund for Strategic Investments and the introduction of technical improvements for this Fund and for the European Investment Advisory Centre. Brussels, 14.9.2016. \{SWD (2016) 297 final\} \{SWD (2016) 298 final\}.

5 Regulation (EU) 2015/1017 of the European Parliament and of the Council of 25 June 2015 , concerning the European Fund for Strategic Investments, the European Investment Advisory Centre and the European Investment Projects Portal, and by which Regulations (EU) No. 1291/2013 and (EU) No. 1316/2013 - the European Fund for Strategic Investments, OJ L 169 of 1.1.2015, are amended.
} 
obstacles to private investment ${ }^{6}$ - facilitating access to financing through a single point for the submission of applications -, and the development of economically viable projects that have a safety mechanism for investments in risky environments. In this regard, the Commission will study the possibility of the EU becoming a shareholder in the Development Bank of the Council of Europe, as called for in the Communication of 7 June 2016, as an additional means of contributing to a coordinated European approach to migration as well as being a complement to the Foreign Investment Plan (COM (2016) 581 final: 10, note 15).

As stated in the proposal for a regulation on the EFSD (COM (2016) 586), the strategic objective pursued is 'to support investments in regions outside the EU as a means of addressing the root causes of migration'. The specific objective will be 'to generate an integrated set of measures aimed at financing investments in the EU's external regions, which would generate employment and growth opportunities, maximize additionality, provide innovative products and attract funds to the private sector'.

The following Graph outlines the proposed operation of the EIP, based on the guarantee of the new European Fund for Sustainable Development, in addition to several combined funding mechanisms from the EU, Member States, other institutions and private investors. The objective is to mobilize investments for a total of 44,000 million euros, starting with an initial contribution of 3,350 million euros. These investments - taking into account the specific characteristics of each country - would be earmarked for infrastructure (energy, water, transport, information and communication technologies, the environment, social infrastructure, etc.), human resources, access to the financing of SMEs and micro-enterprises, and the creation of employment, especially for young people and women.

\footnotetext{
${ }^{6}$ The EU's interest in supporting the private sector is not confined to the scope of our study, but also includes other developing countries, as indicated in the following document from the European Commission: COM (2014) 263 final. Strengthen A Stronger Role of the Private Sector in Achieving Inclusive and Sustainable Growth in Developing Countries. Communication from the Commission to the European Parliament, the Council, the European Economic and Social Committee and the Committee of the Regions. Brussels, 13.5.2014.
} 
Graph 1. Functioning of the European External Investment Plan
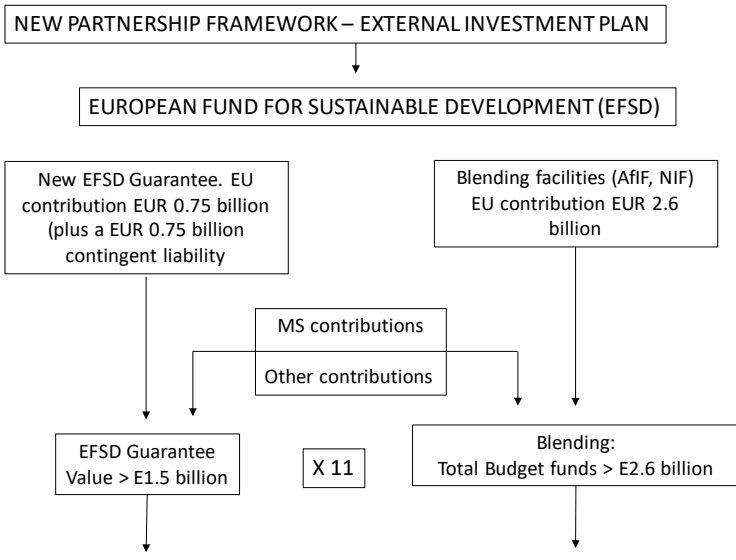

Total extra investment through the Africa and Neighbourhood
Investment Platforms:
at least $€ 44$ billion

Source: COM (2016) 581 final, 11.

\section{FROM THE NEIGHBOURHOOD POLICY TO THE EASTERN PARTNERSHIP}

The neighbourhood policy ${ }^{7}$ arose from the need to create a border area with the new Member States after the great enlargement of 2004, completed in 2007 with the accession of Romania and Bulgaria. It is also a way of managing relations with the post-Soviet region, although the Mediterranean area was later incorporated into the Neighbourhood Policy, starting with the so-called Barcelona Process.

The ENP was presented in 2004 as an alternative to enlargement and was designed following the accession policy -hence its financial precedents are within the framework of the INTERREG, Tacis, Meda, PHARE and CARDS programs ${ }^{8}$ - in order to create a ring of friendly countries around the European Union. In fact, the interest in maintaining and reinforcing it, lies in the fact that authoritarianism and corruption -the main causes of political instabilitygenerate externalities that directly affect the EU. One could cite, among others, illegal immigration, cross-border criminal networks and energy insecurity (Börzel and Hüllen, 2014: 1033).

Although the accession process is taken as a reference in its definition, it was not included among its objectives, but integration with the Union and convergence with the European model was. As Amato (2008: 164-165)

${ }^{7}$ For a theoretical approach to the Neighbourhood Policy, see Kostanyan, H. (2017): Assessing the European neighbourhood policy. London: Rowman \& Littlefield International.

${ }^{8}$ COM (2003) 393 final. Paving the Way for a New Neighbourhood Instrument. Communication from the Commission. Brussels, 1.7.2003. 
recalls, 'one of the main contradictions of the ENP is precisely the lack of economic and political counterparts that are of such importance that they can act as stimulus for the realization of the reforms, such as the perspective of accession for the candidate countries'. A similar idea has been developed by Kochenov (2011), who also states that the extension to the Eastern Partnership was led by Poland, whose interests were mainly focused on Ukraine. However, the Eastern Partnership has been incorporated - and this is confirmed by the Prague Declaration (May 7, 2009) - as a dimension of the ENP, and not as a new line of independent relations ${ }^{9}$. This circumstance clearly clashed with the idea of the new Member States to articulate a regional area around Ukraine, Moldova, the Caucasus Republics and, most likely, also Belarus (Kochenov, 2011: 7).

Faced with the highly unlikely prospect for EU accession, the ENP promotes political cooperation, close economic integration and access to the EU market as an incentive to undertake economic and institutional reforms in order to improve social cohesion in these countries. The economic effects of this Neighbourhood Policy would allow neighbouring countries to benefit in the medium and long term (López-Tamayo, Ramos and Suriñach, 2016: 3). Guinea Llorente (2008: 809-810) notes that the neighbour statute that includes the ENP is a permanent constitutional statute, midway between membership and association, and is supported on positive conditionality.

In the evolution of the ENP and its objectives, the Treaty of Lisbon is of particular importance. Previously, and without it being explicitly mentioned, the Neighbourhood Policy was initially included under the heading of 'development cooperation' in the Treaties of Maastricht (1993 - Title XVII: Articles 130U-130Y) and Amsterdam (1999 - Title XX: Articles 177-181). In the Treaty of Nice (2002), it was included in the 'Economic, financial and technical cooperation with third countries' (Title XXI: Article 181A). However, in 2009, without dismissing all the above, a new Article 8 was incorporated specifying the competences of the EU, gaining a certain autonomy with respect to the Member States. This also provides cohesion to the proposals laid out by the Commission, which only needs the support of the Council.

After an initial start-up phase, the ENP was structured around an own instrument for the 2007-2013 programming period. The European Neighbourhood and Partnership Instrument (ENPI)'10 'aims at sustainable development and the approximation of EU policies and standards and operates within the framework of existing bilateral agreements between the Community and neighbouring countries. In particular, it supports the ENP Action Plans, but is not limited to them, but also supports measures aimed at progressive participation in the EU internal market' (Amato, 2008: 167). As indicated

\footnotetext{
${ }^{9}$ For a critical analysis of the relationships between the ENP, the Eastern Partnership and the EU, see Korosteleva, E. A (2011): "Change or Continuity: Is the Eastern Partnership an adequate tool for the European Neighbourhood?" International Relations, 25(2) 243-262.

${ }^{10}$ Regulation (EC) No 1638/2006.
} 
in the Regulation of the ENPI (No. 1638/2006), the financial envelope for the period spanning 2007-2013 would be 11,181 million euros, of which 95 per cent would be allocated to national or plurinational programs, and the remaining 5 per cent to cross-border cooperation programs, taking into account that investments will be made in two sub-periods (2007-2010 and 20112013) ${ }^{11}$. The following Graph shows the complexity of the ENP financing, in which, in addition to the ENPI - which includes the Neighbourhood Investment Facility (NIF), the Investment Instrument for the Neighbourhood Policy-, other instruments such as the ERDF in the cross-border programs and the European Investment Bank are involved ${ }^{12}$. The ENI programs include thematic areas related to vocational training, university studies, the European Research Area (ERA), and the protection of the environment and nature. In addition, the European Instrument for Democracy and Human Rights, the Instrument for Nuclear Safety and Cooperation, and the Instrument for Development Cooperation intervene in the thematic programs.

Graph 2. Financing and programs of the Neighbourhood Policy (2007-2013)

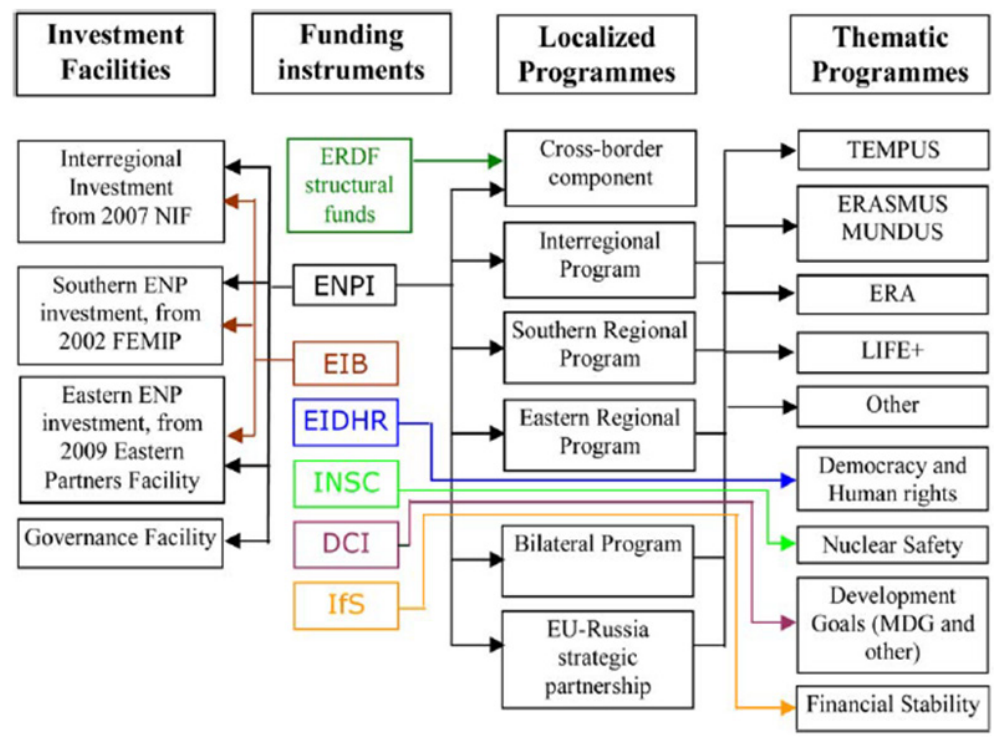

Source: Wessenlink, Boschma (2017: 9).

${ }^{11}$ COM (2011) 303 final. A new response to a changing neighbourhood. Joint communication to the European Parliament, the Council, the European Economic and Social Committee and the Committee of the Regions. Brussels, 25.5.2011.

${ }_{12}$ During this programming period, there are other platforms for investments or the attraction of foreign investment such as East Invest [http://www.east-invest.eu/en/about-east-invest], made up of the European Association of Chambers of Commerce in collaboration with the countries of the Eastern Association. 
The revision of the European Neighbourhood Policy, starting with the Riga Summit $(2015)^{13}$, establishes three major pillars of priority areas (see Table 1): economic development for stabilization, security dimension, and migration and mobility. The first of these includes areas in which both the ENP and the EU are already working on through the European Investment Plan: trade, modernization and entrepreneurship, employment and employability with special attention on youths, cooperation for growth, transport and connectivity, and energy security and the fight against climate change.

Table 1. Proposals for common cooperation priorities. European Neighbourhood Policy (2015)

\begin{tabular}{|c|c|c|}
\hline PRIORITARY AREAS & PROPOSALS & \\
\hline \multirow{6}{*}{$\begin{array}{l}\text { Economic develop- } \\
\text { ment for stabilization }\end{array}$} & Trade & $\begin{array}{l}\text { Creation of an In-depth and Comprehensive } \\
\text { Free Trade Area (DCFTA): Ukraine, Moldova and } \\
\text { Georgia } \\
\text { Less exhaustive and more flexible trade agree- } \\
\text { ments for those who do not join the DCFTA }\end{array}$ \\
\hline & $\begin{array}{l}\text { Economic moderni- } \\
\text { zation and entrepre- } \\
\text { neurial spirit }\end{array}$ & $\begin{array}{l}\text { Smart and sustainable growth } \\
\text { Support for SMEs }\end{array}$ \\
\hline & $\begin{array}{l}\text { Employment and } \\
\text { employability with } \\
\text { special attention on } \\
\text { youths }\end{array}$ & $\begin{array}{l}\text { Special support for vocational training pro- } \\
\text { grams and Erasmus }+.\end{array}$ \\
\hline & $\begin{array}{l}\text { Cooperation for } \\
\text { growth }\end{array}$ & $\begin{array}{l}\text { Search for an increase in investment and eco- } \\
\text { nomic modernization with greater participation } \\
\text { of the private sector. }\end{array}$ \\
\hline & $\begin{array}{l}\text { Transport and con- } \\
\text { nectivity }\end{array}$ & $\begin{array}{l}\text { Inclusion in the TEN-T (Trans-European trans- } \\
\text { port network) }\end{array}$ \\
\hline & $\begin{array}{l}\text { Energy security and } \\
\text { the fight against } \\
\text { climate change }\end{array}$ & Links to the Energy Union \\
\hline Security dimension & & $\begin{array}{l}\text { Priority will be given to the fight against terro- } \\
\text { rism and the prevention of radicalization, the } \\
\text { dismantling of organized cross-border crime } \\
\text { and corruption, the improvement of judicial } \\
\text { cooperation in criminal matters, and the fight } \\
\text { against computer crime. }\end{array}$ \\
\hline Migration and mobility & & $\begin{array}{l}\text { Increase in cooperation } \\
\text { Support for refugee assistance } \\
\text { Cooperation in irregular migration and forced } \\
\text { displacement, and in related matters. } \\
\text { Academic collaboration }\end{array}$ \\
\hline
\end{tabular}

Source: European Commission JOIN (2015) 50 final.

${ }^{13}$ Texts from all the Eastern Partnership Summits can be consulted at: European Council. Eastern Partnerships http://www.consilium.europa.eu/es/policies/eastern-partnership/ 
The new European Neighbourhood Instrument (ENI), adopted in 2014, contributes 15,400 million euros for the period spanning 2014-2020 (JOIN (2015) 9 final). For this period, the framework of cross-border cooperation ${ }^{14}$ has also been renewed, including, in our study area, five border programs (LatviaLithuania-Belarus, Poland-Belarus-Ukraine, Hungary-Slovakia-Romania-Ukraine, Romania-Ukraine and Romania-Moldova) and a regional program around the Black Sea. The program has three strategic objectives: to favour socioeconomic development; implement common changes for matters related to the environment, public health and safety; and facilitate the mobility of people, goods and capital. Its financial allocation amounts to 5 per cent of the total.

In regard to the bilateral programs -Action Plans- signed with each of the States ${ }^{15}$, as well as the plurinational programs, the ENI Regulation (Annex II) includes the priorities of EU assistance, which are very similar in both cases. They make reference to aspects such as human rights, governance and the rule of law; institutional cooperation and capacity building; regional cooperation (in the case of plurinational programs) and social and territorial cohesion (in bilateral programs); higher education and skills development, mobility of students and teaching staff, youth and culture; sustainable economic development, development of trade and the private sector and aid to Small and Medium Enterprises; the energy sector, in particular energy networks; interconnections of transport and infrastructure; sustainable management of natural resources, in particular water, ecological growth, the environment and adaptation and mitigation of climate change; help to civil society; mobility and migration management; and development of trusts and other measures that contribute to the prevention and resolution of conflicts. Regarding the financial allocation, the Action Plans absorb up to 80 per cent of the total allocation, while plurinational programs receive up to 35 per cent.

The following Table shows the approximate allocation - with a wide range between minimum and maximum amounts that constitutes an additional difficulty in the quantification of the application of the ENP in the Eastern Partnership countries - of the Funds for the 2014-2017 period. However, what is most significant is the distribution of these funds, which clearly differs according to the main needs of each State, and highlights what is likely to be the main investment challenges, as we will see in the next section.

\footnotetext{
14 SWD (2015) 77 final.

${ }^{15}$ The political situation of Belarus, led by a non-democratic regime, has led the EU to sign a unilateral program with this country. The European Council will extend the restrictive measures against Belarus until February 2019. All the Action Plans with the Eastern Partnership can be consulted in The ENP Action Plans - Association Agendas for Eastern partner countries https://eeas.europa.eu/topics/ european-neighbourhood-policy-enp/8398/-enp-action-plans_en.
} 
Table 2. Multiannual approximated (millions of Euros) provisions and fund allocation for 2014-2017 FOR THE COUNTRIES IN THE EASTERN PARTNERSHIP

\begin{tabular}{|l|l|l|l|}
\hline Country & \multicolumn{2}{|c|}{ ENI for 2014-2017 } & \multicolumn{1}{|c|}{ Fund allocation } \\
\hline & Minimum & Maximum & \\
\hline Belarus & 71 & 89 & $\begin{array}{l}\text { Social inclusion 30 per cent } \\
\text { Environment 30 per cent } \\
\text { Local and regional economic development 30 per cent } \\
\text { Complementary support to civil society 10 per cent }\end{array}$ \\
\hline Ukraine & 140 & 200 & $\begin{array}{l}\text { Development of the private sector 40 per cent } \\
\text { Energy sector 40 per cent } \\
\text { Complementary support to the development capacity } \\
\text { and to } \\
\text { civil society 20 per cent }\end{array}$ \\
\hline Moldova & 335 & 410 & $\begin{array}{l}\text { Agriculture and rural development 30 per cent } \\
\text { Public administration reforms 30 per cent } \\
\text { Political reform and border management 20 per cent } \\
\text { Complementary support to the development capacity } \\
\text { and to civil society 20 per cent }\end{array}$ \\
\hline Georgia & 335 & 410 & $\begin{array}{l}\text { Agriculture and rural development 30 per cent } \\
\text { Public administration reforms 25 per cent } \\
\text { Justice reform 25 per cent } \\
\text { Complementary support to the development capacity } \\
\text { and to civil society 20 per cent }\end{array}$ \\
\hline Armenia & 140 & 170 & $\begin{array}{l}\text { Development of the private sector 35 per cent } \\
\text { Public administration reforms 25 per cent } \\
\text { Justice reform 20 per cent } \\
\text { Complementary support to the development capacity } \\
\text { and to civil society 20 per cent }\end{array}$ \\
\hline Anerbaijan & 77 & $\begin{array}{l}\text { Regional and rural development 40 per cent } \\
\text { Justice reform 20 per cent } \\
\text { Development of education and capacities 20 per cent } \\
\text { Complementary support to the development capacity } \\
\text { and to civil society 20 per cent }\end{array}$ \\
\hline
\end{tabular}

Source: Sandu and Dragan (2016: 467).

\section{THE FOREIGN INVESTMENT PLAN AND THE COUNTRIES OF THE EASTERN PARTNERSHIP}

The 2008 crisis has meant a halt to growth for the eastern Asian and Central Asia countries after a decade of growth in which the GDP had increased and unemployment and public debt had reduced. Likewise, exports have suffered, which, until then, (except in the case of Belarus who have signed a trade agreement with the Russian Federation) were mainly destined for the EU. The extension of the crisis to the Member States reduced commercial trading, who then looked to market in Asia, whose economies had withstood the crisis better (European Commission, 2009).

The link between the EIP and the ENP is based on the fact that the European Investment Plan not only offers safety guarantees but has also helped to 
create a favourable climate for investment. This is the model on which the new investment lines for the Eastern Partnership will be based. It responds to Article 8.1 of the Treaty on European Union, according to which 'The Union shall develop a special relationship with neighbouring countries, with the aim of establishing an area of prosperity and good neighbourliness, founded on the values of the Union and characterised by close and peaceful relations based on cooperation'.

The EIP becomes an investment mechanism of the Neighbourhood Policy with revised objectives and new tasks, as previously mentioned. It also seeks to modify traditional development aid that has thus far proven to not favour sustainable development, a complicated issue due to the climate of economic and socio-political instability in recent years. However, it is important to note that, in the current 2014-2020 period, the investment approach in the neighbourhood countries is undergoing a major change. There is a clear tendency to analyse the region not as a unified set, but as a series of countries that individually have their own characteristics, and specific needs. In this sense, Castell-Quintana and Royuela (2016), in an analysis on the role of infrastructure in the development of accumulated economies, pointed out the need for the EIB to address the specific needs of each neighbouring State in its projects, adapting to its specific socio-economic and geographical characteristics.

One way of approaching the economic and socio-political situation of each country and having the ability to identify the main problems when investing, is by employing the Global Competitiveness Index. Some basic factors are necessary to boost the economy, among which include institutions, infrastructures, a favourable macroeconomic environment, a healthcare system and a compulsory education system. With this, it is possible to develop the second block of elements linked to efficiency, and a third that includes factors of innovation and business complexity (Schwab, 2014: 9).

The following Graph shows the reference of the Global Competitiveness Index in the countries in our study. In each case we have included data from Germany, Poland and Romania, in order to offer several references: the first as the main economic driver of the EU, and the second two as border countries with direct interests - especially in the Polish case - in the reinforcement of the Neighbourhood Policy. It includes twelve values that correspond to the three pillars of the index: institutions, infrastructures, macroeconomic context, and health and primary education in the first pillar; university education and training, efficiency of the goods market, efficiency of the labour market, development of the financial market, technological preparation, and size of the market in the second pillar; and, finally, the third pillar includes factors of business and innovation complexity. 
Graph 3. Global Competitiveness Index for the countries of the Eastern Partnership (2015)

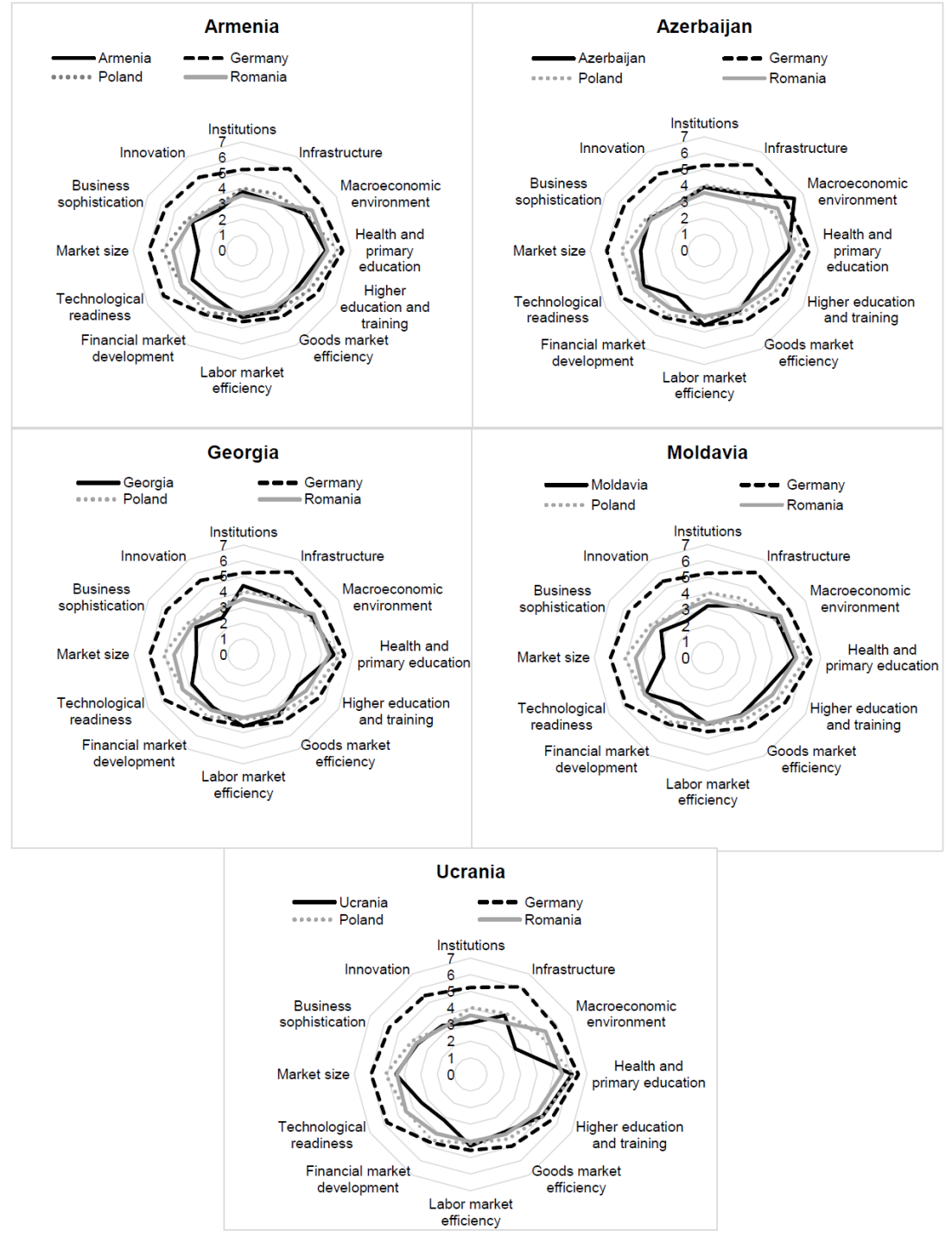

Source: World Economic Forum (2015). Own elaboration.

The Report for the World Economic Forum (2015), corresponding to 20152016, also includes the main challenges investment faces in the countries of study. In the case of Armenia, the five most problematic challenges are (listed 
in order of importance): access to finance, inefficient government bureaucracy, foreign exchange regulations, lack of adequate employee preparation, and corruption. For Azerbaijan, the greatest difficulties are found in corruption, access to finance, taxes, lack of adequate employee preparation, and obsolete infrastructure. In Georgia, ranked first is an unskilled labour force, followed by access to finance, obsolete infrastructures, inflation and political instability. In Moldova, corruption is the main challenge followed by political instability, bureaucratic inefficiency, government instability and access to financing. As in the previous case, corruption ranks first among the challenges faced by Ukraine, followed by access to finance, inflation, political instability, and taxes.

The 2016 and 2017-2018 reports show some changes that reflect the great instability that the region is experiencing, especially in the territories that border the EU.

In the case of Armenia, the competitiveness index went from 82 to 79 (out of 138 countries analysed) in 2016 and to 73 (over 137 countries analysed) in 2017, and its GDP per capita improved (\$ 3534.9) in 2016, slightly reduced in the following two years $(\$ 3,510.7)$. However, in 2016 corruption ranked second among the factors that hold back investment, while in 2017 the main impediments to investment are access to financing, tax rates, and regulation of these. Azerbaijan, on the other hand, also improves its competitiveness index, ranking 37 (2016) and 35 a year later. However, it has reduced its GDP per capita by $\$ 4,000$ over the period analysed. In 2016, it seemed to have controlled the weight of corruption, with inflation becoming the second concern. However, in the 2017-2018 report, corruption ranks seventh, surpassed by access to financing, the foreign currency regulations and tax regulations, the inflation, the inefficient government bureaucracy, and the inadequately educated workforce. As for Georgia, in 2016 it had improved both its Competitiveness Index, ranking 59th, and its GDP per capita, which stood at \$3788.60. In 2017 it ranks 65th, although the factors that hinder investment have not changed in this case. The Republic of Moldova had a much worse economic and competitiveness situation- although the 2017 index and GDP per capita have improved slightly -, probably caused by an increase in corruption and political instability. Something similar happened with Ukraine. Its economic and political situations had worsened, and this was reflected in a decline in the Competitiveness Index ${ }^{16}$.

On 23 November 2017 the European Commission approved 5 investment windows or priority investment areas: Sustainable Energy and Connectivity, Micro, Small and Medium Sized Enterprises (MSMEs) Financing, Sustainable Agriculture, Rural Entrepreneurs and Agribusiness, Sustainable Cities, and

\footnotetext{
${ }^{16}$ The latest report published in 2018 presents a new methodology in order to adapt the analysis to the effects of the recession of 2008 and the gathering pace of the Fourth Industrial Revolution. The Global Competitiveness Index 4.0 is organized into 12 pillars grouped in 4 blocks: Enabling environment (institutions, infrastructure, ICT adoption, macroeconomic stability), Human capital (health, skills), Markets (product market, labour market, financial system, market size), Innovation ecosystem (business dynamism, innovation capability).
} 
Digital for Development. Some examples of projects financed by the EU within the EU4Business initiative ${ }^{17}$ are EFSE (Neighbourhood window of the European Fund for South East Europe), DCFTA Direct Finance (Georgia, Moldova, Ukraine) and SME Finance Facility - Phase II (Ukraine). Within the E5P Fund ${ }^{18}$ there are $^{2}$ several projects financed by loans from the Council of Europe Development Bank (CEB), the European Bank for Reconstruction and Development (EBRD), the European Investment Bank (EIB), the International Finance Corporation (IFC), the Kreditanstalt fur Wiederaufbau (KfW), the Nordic Environment Finance Corporation (NEFCO), the Nordic Investment Bank (NIB), and the World Bank (WB). The sectors that benefit from the fund are: District heating, energy efficiency in public buildings (schools, kindergartens, hospitals), energy saving measures in residential housing, renewable energy (including biomass), street lighting, water and wastewater treatment, solid waste management, and urban transport. Azerbaijan does not currently have any projects.

These projects were launched in 2009, but since 2017 they are guaranteed by the European External Investment Plan in order to attract private investors in addition to current donors, among which are the EBRD, the KfW, the EIB Group, and others.

\section{FINAL REFLECTIONS}

The socio-economic characteristics of the Eastern Partnership constitute one of the greatest challenges for the application of the EIP. The ESPON Report (2012) has already emphasized the need to consider territorial dimension in the application of the ENP. Likewise, Kallioras, Monastiriotis and Petrakos (2016) highlight the agglomeration of the population in certain regions and emphasise the need for the EU, through its Neighbourhood Policies, to support those regions that, as a result of the strong rural exodus, are at most disadvantage. The demographic differences of the neighbour countries with respect to the EU add to this problem. They have a younger population, a strong rural exodus and, in recent years, an increase in migratory flows linked to armed conflicts and unstable political situations.

Some authors speak of the need for "positive conditionality" for neighbouring countries when receiving funds from European programs (Grant, 2011:10). The Copenhagen criteria ${ }^{19}$ requirement greatly hinders relations with neighbouring States, especially when the incentive for future accession

\footnotetext{
17 http://www.eu4business.eu/

${ }^{18}$ Eastern Europe Energy Efficiency and Environment Partnership: E5P http://e5p.eu/

${ }^{19}$ The European Council in Copenhagen (21-22 June 1993) approved three basic criteria, required by those States that wanted to join the European Union: a political criterion that refers to the existence of stable institutions that guarantee democracy, the rule of law, respect for human rights, and respect and protection of minorities; an economic criterion related to the existence of a viable market economy, as well as the ability to cope with competitive pressure and market forces within the Union; and, finally, the acceptance and incorporation of the Community.
} 
to the European Union is not present. In spite of this, the fulfilment of these criteria is sought, partly because the absence of the elements that constitute them hinders economic development and in national terms, with the investment policy, pose obstacles to the competitiveness of countries and projects. To encourage governments to undertake the necessary reforms, they resort to facilitating some bureaucratic procedures such as the obtainment of visas or guaranteeing access to European markets (Ademmer and Börzel, 2013). Nor should we forget that, according to Guinea Llorente (2008: 809, note 14), "Each of the ENP Action Plans begins with the sentence: "The ENP sets ambitious objectives for the association with neighbouring countries, based on the commitment to shared values, key foreign policy objectives and political, economic and institutional reforms ${ }^{20 "}$.

The "Europeanisation" of neighbourhood"21, or the attempt to carry it out, many times becomes more of a problem than a way of implementing policies that could put an end, or at least improve, three of the great problems that this region faces: corruption -linked to the democratic deficit and political instability-, the lack of modern energy infrastructures, and migration.

Moscow's interest in creating an area under its economic and political influence that encompasses the former Soviet Republics, to which the countries of the Eastern Partnership once belonged, means the necessary reforms "demanded" by Brussels for public investment are particularly difficult to obtain. This could also be a hindrance to developing the European External Investment Plan and revitalizing private investment. With regard to the latter, Ascani, Crescenzi and lammarino (2017: 78) note that among the factors that determine foreign investment are firstly the domestic demand, the potential market and wages; and secondly, proximity to the EU, economic integration of the region, institutional development and fiscal incentives.

The Neighbourhood Policy, and in particular relations with the Eastern Partnership, also faces the challenge of globalization. The difficulty of maintaining direct relations with neighbours increases, as also happens between regions and Member States of the EU. In this sense, the European External Investment Plan is a good opportunity to strengthen these ties while helping to eliminate some of the aforementioned barriers to investment or difficulties in meeting the objectives of competitiveness. The support to the small and medium enterprises guarantees socioeconomic improvements with

\footnotetext{
${ }^{20}$ On the objective and capacity for democratization of the ENP, see Freyburg, T.; Lavenex, S.; Schimmelfennig, F.; Skripka, T.; Wetzel, A. (2011): "Democracy promotion through functional cooperation? The case of the European Neighbourhood Policy", Democratization, Vol. 18, n ${ }^{\circ}$, pp. 1026-1054.

${ }^{21}$ In parallel to the neighbourhood programs, the EU carries out an action called OPEN Neighbourhood, aimed at strengthening relations with the inhabitants of the region in order to better understand EU funding and promote the process of democratization. See Annual Survey Report: Regional overview - Eastern Partnership Countries. OPEN Neighbourhood - Communicating for a stronger partnership: connecting with citizens across the Eastern Neighbourhood. July 2016. http://www.euneighbours.eu/ sites/default/files/publications/2017-02/EU\%20Neighbours\%20East_Full.report_6.pdf.
} 
diverse effects such as the reduction of the rural exodus or a higher labour qualification. The model of financing through subsidies and guaranteed loans favours private investment and gives decision-making power to municipalities to carry out projects that benefit their population. Indirectly, institutions are reinforced at the local level, which can contribute to the reduction of corruption and the strengthening of democracy.

\section{REFERENCES}

Ademmer, E., Börzel, T.A. (2013): "Migration, energy and good governance in the EU's Eastern Neighbourhood”, Europe-Asia Studies, 65 (4), $581-608$.

Amato, A. (2008): "Auge y declive de la Política Europea de Vecindad", Anuario IEMed del Mediterráneo 2008, 163-167.

Ascani, A., Crescenzi, R., lammarino, S. (2017): "The geography of foreign investments in the EU neighbourhood”, Tijdschrift voor economische en sociale geografie, 108 (1), 76-91.

Börzel, T. A., Van Hüllen, V. (2014): "One voice, one message, but conflicting goals: cohesiveness and consistency in the European Neighbourhood Policy", Journal of European Public Policy, 21 (7), 1033-1049.

Bratislava Declaration and roadmap. http://www.consilium.europa.eu/en/press/ press-releases/2016/09/16-bratislava-declaration-and-roadmap/

Castells-Quintana, D., Royuela, V. (2016): "Spatially blind policies? Analysing agglomeration economies and European Investment Bank funding in European neighbouring countries", The Annals of Regional Science, 1-21. doi: 10.1007/s00168-016-0784-3

COM (2003): 104 final. Communication from the Commission to the Council and the European Parliament - Wider Europe - Neighbourhood: A New Framework for Relations with our Eastern and Southern Neighbours. Comission of the European Communities, Brussels.

COM (2008) : 823 final COMMUNICATION DE LA COMMISSION AU PARLEMENT EUROPÉEN ET AU CONSEIL Partenariat oriental \{ SEC (2008) 2974 \} Bruxelles, le 3.12.2008

COM (2016): 359 final - Europe investing again. Taking stock of the Investment Plan for Europe and next steps.

COM (2016): 581 final - Strengthening European Investments for jobs and growth: Towards a second phase of the European Fund for Strategic Investments and a new European External Investment Plan. Communication from the Commission to the European Parliament, the Council, the European Central Bank, the European Economic and Social Committee, the Committee of the Regions and the European Investment Bank, Brussels, 14.9 .2016 .

COM (2016): 586 final-Proposal for a Regulation of the European Parliament and of the Council on the European Fund for Sustainable Development (EFSD) and establishing the EFSD Guarantee and the EFSD Guarantee Fund. 
European Council. Eastern Partnership http://www.consilium.europa.eu/en/ policies/eastern-partnership/.

ESPON (2012): Europe's Neighbourhood from a Territorial Perspective. Report from the ESPON Internal Seminar 5-6 December 2012 in Paphos - Cyprus.

EU Neighbours. http://www.euneighbours.eu/.

European Commission (2009): "Impact of the global crisis on neighbouring countries of the EU”, Occasional Papers No 48, Directorate-General for Economic and Financial Affairs.

European Commission (2015): Support for the Eastern Partnership. Stories, facts and figures from the European Neighbourhood Instrument 2014. Directorate-General for Neighbourhood and Enlargement Negotiations, Luxembourg: Publications Office of the European Union.

European Commission (2016): European Structural and Investment FUNDS and European Fund for Strategic Investments complementarities - Ensuring coordination, synergies and complementarity. http://ec.europa.eu/ regional_policy/sources/thefunds/fin_inst/pdf/efsi_esif_compl_en.pdf

European Neighbourhood Policy and Enlargement Negotiations https:// ec.europa.eu/neighbourhood-enlargement/.

EY (2016): Ad-hoc audit of the application of the Regulation 2015/1017 (the EFSI Regulation). Final Report, European Union. https://ec.europa.eu/ commission/sites/beta-political/files/ey-report-on-efsi_en.pdf

García Nicolás, C. (2016): "La competitividad territorial y el Plan Europeo de Inversiones frente a la desigualdad regional”, Investigaciones Regionales - Journal of Regional Research, 35 (Secciōn Política Regional Europea), 177-201.

Grant, Ch. (2011): "A new neighbourhood policy for the EU”, Centre for European Reform, Policy Brief. http://cer-staging.thomas-paterson. co.uk/sites/default/files/publications/attachments/pdf/2011/pb_grant_ neighbourhood_11 march11-170.pdf

Guinea Llorente, M. (2008): "La política europea de vecindad y la estabilización del entorno próximo: el caso de Europa oriental”, Revista de Derecho Comunitario Europeo, 31, 805-831.

JOIN (2015): 9 final. Joint Communication to the European Parliament, the Council, the European Economic and Social Committee and the Committee of the Regions. Implementation of the European Neighbourhood Policy in 2014. Brussels, 25.3.2015.

Kallioras, D., Monastiriotis, V., Petrakos, G. (2016): "Spatial dynamics and agglomeration forces in the external EU periphery”, Annals of Regional Science, Special Issue Paper, DOI 10.1007/s00168-016-0798-x.

Kochenov, D. (2011): "New developments in the European Neighbourhood Policy: Ignoring the problems”, Comparative European Politics, 9, 4/5, 581-585.

López-Tamayo, J., Ramos, R., Suriñach i Caralt, J. (2016): “Economic performance, social progress and institutional reform in European neighbouring countries". The Annals of Regional Science, Special Issue Paper. doi: 10.1007/s00168-016-0785-2 
Programming of the European Neighbourhood Instrument (ENI) - 2014-2020. Strategic Priorities 2014-2020 and Multi-annual Indicative Programme 2014-2017. European Neighbourhood-wide measures. European External Action Service. European Commission. Directorate General for Development and Cooperation - Europeaid.

Regulation (EC) No 1638/2006 of the European Parliament and of the Council of 24 October 2006 laying down general provisions establishing a European Neighbourhood and Partnership Instrument.

Regulation (EU) No 234/2014 of the European Parliament and of the Council of 11 March 2014 establishing a Partnership Instrument for cooperation with third countries.

Sandu, I., Dragan, G. (2016): "Financing the EU neighbourhood - Key facts and figures for the eastern partnership", CES Working Papers - Volume VIII, Issue 3, 464-472. http://econpapers.repec.org/article/jeswpaper/

Schwab, K. (ed.) (2018): The Global Competitiveness Report 2018: Full Data Edition, World Economic Forum, Geneva.

-(2017): The Global Competitiveness Report 2017-2018: Full Data Edition, World Economic Forum, Geneva.

-(2016): The Global Competitiveness Report 2016-2017: Full Data Edition, World Economic Forum, Geneva.

-(2015): The Global Competitiveness Report 2015-2016: Full Data Edition, World Economic Forum, Geneva.

-(2014): The Global Competitiveness Report 2014-2015: Full Data Edition, World Economic Forum, Geneva.

SWD (2015): 77 final. Joint Staff Working Document. Implementation of the European Neighbourhood Policy Statistics Accompanying the document Joint Communication to the European Parliament, the Council, the European Economic and Social Committee and the Committee of the Regions. Implementation of the European Neighbourhood Policy in 2014. Brussels, 25.3.2015.

Wesselink, E., Boschma, R. (2017): “European Neighbourhood Policy: history, structure, and implemented policy measures", Tijdschrift voor economische en sociale geografie, 108 (1), 4-20. 